\title{
Learners' preferences of oral corrective feedback: An example of Turkish as a foreign language learners
}

\author{
Dilek Fidan \\ Kocaeli University, Turkey. \\ Received 05 March, 2015; Accepted 30 April, 2015
}

\begin{abstract}
The aim of this study is to investigate the oral corrective feedback (OCF) preferences of learners of Turkish as a foreign language (TFL) in order to understand whether they would like their errors to be corrected and, if so, when, which of them, how and by whom they would like to be corrected in the classroom environment. A questionnaire with multiple choices, adapted from the review of Hendrickson (1978), was administered to 165 TFL learners. A total of 141 of the participants were C1 level learners, and 24 of them were B2 level learners. The results show that the vast majority of the participants (97. \%) prefer their errors to be corrected, and a smaller majority of them prefer teachers $(73.2 \%)$ to correct them immediately $(58.9 \%)$. Just over half $(54 \%)$ of the participants primarily prefer grammatical errors to be corrected; the most preferred correction strategy $(43 \%)$ is teachers giving the correct form immediately and the second most preferred correction strategy $(21.2 \%)$ is teachers repeating the erroneous part of the utterance.
\end{abstract}

Key words: Second language acquisition, classroom discourse, error correction, error treatment.

\section{INTRODUCTION}

As in every learning environment, the errors of the students are unavoidable in foreign/second language environments. There are many variables - such as intelligence, personality, aptitude, gender, motivation, ethnicity and expectations of the learner - that affect foreign and second language development. The teachers' responses to the errors (whether syntactic, lexical, semantic, phonetic, pragmatic, or otherwise) are called corrective feedback (CF). Walsh (2013) states that classroom discourse has a fairly typical and predictable structure, which has three parts: the Initiation of the teacher, the Response of the student and the Feedback of the teacher - commonly abbreviated as IRF - and feedback in this order allows a learner to see whether their response has been accepted or not. The types of CF in general are oral CF and written CF. The current study is concerned with oral CF. At the beginning of sixties, errors were viewed as the facts that have to be corrected, but by the end of the decade they had become tools for learning (George, 1972 in Hendrickson, 1978). Properly chosen feedback positively enhances students' learning. In other words, errors are the tools to develop learning, if proper CF is provided, because every learner expects to be corrected. The study of Katayama (2007) found that the majority of Japanese ESL students prefer their pragmatic errors to be corrected as well as the other kinds of errors. She relates this situation to the education system of Japan: junior and senior high school students

\section{E-mail: dilekfidan@yahoo.com}

Authors agree that this article remain permanently open access under the terms of the Creative Commons Attribution License 4.0 International License 
are taught grammar-oriented English and they also have a wide range of vocabulary, so this is why they need mostly to improve their pragmatic usage of English, and require pragmatic feedback.

According to Chaudron (1977, p.31), CF is 'any reaction of the teacher which clearly transforms, disapprovingly refers to, or demands improvement of the learner utterance'. It is implied that CF's are primarily used to improve the proficiency of the learner. Language teachers or other students in the classroom can provide $\mathrm{CF}$, as can native speakers or other non-native speakers in naturalistic settings (Sheen, 2011).

There are various different methods, from simply indicating a lack of comprehension or signaling the occurrence of an error and getting the learner to selfcorrect, to the most elaborate grammatical explanation and drill of correct forms to give learners feedback (Crookes and Chaudron, 1991). Request for clarification, confirmation check, recast, repetition, metalinguistic feedback, elicitation and explicit correction are the most preferred corrective strategies that teachers employ (Ellis, 2008). In Loewen et al. (2009), it is stated that although students may believe that error correction is essential for language learning, there is no consensus on how this error correction should be implemented. Katayama (2007) reached a similar conclusion; nearly half of the participants (47.3\%) in her study disagree that teachers should correct all errors in speaking, and the majority of the participants agreed that the errors that interfere with communication should be corrected. At this point, it is clear that teachers have a critical position; they are the decision makers responsible for choosing the CFs and, in addition to pedagogical targets, they need to be aware of learners' individual differences, needs, levels and expectations. In Ellis's (2008) review of a number of studies, it is clearly seen that teachers employ various corrective strategies and that factors such as instructional contexts, pedagogic focus, style of teaching, etc, affect the strategies they employ.

Ellis (2008) states that early CF research focused on addressing key theoretical issues and describing the corrective practice of teachers, while later research has attempted to investigate whether CF is taken up by learners and whether it actually assists acquisition. One of the earliest reviews (Hendrickson, 1978) addressing questions about error correction in second language learning yielded the following questions, which also provide the starting point for the present study: '1. Should learner errors be corrected?, 2 . If so, when should learner errors be corrected?, 3. Which learner errors should be corrected?, 4. How should learner errors be corrected?, 5 . Who should correct the learner errors?'. He reviewed a number of studies investigating error correction, and the main conclusions he reached are listed below:

a. If the learners are corrected, they become aware of their mistakes.

b. Correcting all the errors is counter-productive. The important point is to make students feel the supportive classroom environment, make them feel confident, and to avoid them suffering embarrassment for their errors.

c. Errors that seriously impair communication, those that stigmatize learner or reader understanding and those which are frequently produced by learners have higher priority than others.

d. Direct types of corrective procedures are in effective.

e. In addition to teacher correction of learner errors, peercorrection and self-correction would be effective facilitators, but differences of learners and the type of the language classrooms should be considered to choose the best instructional strategy.

\section{METHODOLOGY}

\section{Research questions}

This study aims to find out answers to the research questions posed in the questionnaire, namely:

1. Do TFL learners believe that the errors that they make should be corrected, and what is the breakdown for $\mathrm{C} 1$ and $\mathrm{B} 2$ level students? 2. According to TFL learners, when should learner errors be corrected, and what is the breakdown for $\mathrm{C} 1$ and $\mathrm{B} 2$ level students? 3. According to TFL learners, which learner errors should be corrected, and what is the breakdown for $\mathrm{C} 1$ and $\mathrm{B} 2$ level students? 4. According to TFL learners, how should learner errors be corrected, and what is the breakdown for $\mathrm{C} 1$ and $\mathrm{B} 2$ level students? 5. According to TFL learners, who should correct the learner errors, and what is the breakdown for $\mathrm{C} 1$ and $\mathrm{B} 2$ level students?

\section{Limitations of the study}

Throughout this study, the term oral corrective feedback (OCR) is used to refer to the feedback given in response to an ill-formed usage of the target language by a student. In other words, only the corrections of erroneous usages in oral language are covered by the questionnaire; didactic CF and written CF are beyond the scope of this study.

The reliability of the findings of this study would be increased if the number of participants of different language levels (such as $A 1$, A2 and B1) was increased.

\section{Setting and participants}

The study was carried out at two foreign language teaching centers of two state universities in North-west Turkey at the end of the spring term of the 2013-14 academic year. The participants were international students (aged from 17 to 36 ) who had studied prep Turkish as a foreign language (TFL) classes. Their aim in learning Turkish is to study at Turkish universities as undergraduate or graduate students, and they are expected to pass a TFL certificate exam at the end of the semester. Various native languages and ethnic backgrounds were represented among the participants (including Arabic, French, English, Russian, Uighur, Uzbek, Polish, Spanish, Mongolian, and Persian). There were two groups of TFL learner: The first group consisted of $\mathrm{C} 1$ level learners (N: 141), who are accepted as effective operational proficiency (advanced) level, and the second group consisted of B2 level learners (N: 24) who are accepted as vantage (upper intermediate) level according to the Common European Framework of Reference for Languages (Council of Europe 2001: 23). The total number of learners was 
one hundred and sixty-five (N: 165).

\section{Instrument}

The measurement instrument used in this study was a questionnaire, prepared on the basis of the aforementioned five questions discussed in the review of Hendrickson (1978). Possible answers were adapted from Lyster and Ranta (1997), Ellis (2008) and Sheen (2011) for each question by the author of the present study, and participants were asked to select from the given multiplechoice answers. The questionnaire also included a section about the personal background of participants (age, education, mother language, known foreign language/s and level of Turkish). The content validity of the questionnaire was assessed by two experts (one subject expert and one assessment and evaluation expert) before being given to the students.

\section{Data collection and analysis}

As the first step of the data collection process, all the volunteer participants were informed about the content of the study and they signed a consent form confirming their agreement to take part in the research. Secondly, they filled out the questionnaire, which took about fifteen minutes. Subsequently, the data was collated and analyzed.

\section{FINDINGS AND DISCUSSION}

In the present study, TFL learners' oral corrective feedback (OCF) preferences are investigated in order to discover if they would like their errors to be corrected and, if so, when, which ones, how and by whom they would like to be corrected in the classroom environment. In total, 165 participants of $\mathrm{C} 1$ and B2 level took part in the study, 141 of whom were $\mathrm{C} 1$ and 24 of whom were B2 level students. Table 1 shows the distribution of participants in each group.

A total of $85.5 \%$ of the study sample comprised C1 level participants, while the remaining $14.5 \%$ comprised B2 level participants. The questions were grouped into five categories and each question offered multiple-choice answers. Table 2 displays the OCF choices for each question.

The preferences of the participants regarding OCF patterns are given in the following tables. Participants were asked if they would like to be corrected or not, and their responses are summarized in Table 3.

As can be seen in Table 3, the vast majority of both $\mathrm{C} 1$ and B2 level participants (97.6\%) agree that errors should be corrected. While B2 level participants are unanimous $(100 \%)$ in thinking that errors should be corrected, $97.2 \%$ of the $\mathrm{C} 1$ level participants agree. According to Crookes and Chaudron (1991), even in the most learner-centered instruction, students need feedback because they will see the difference between acceptable and unacceptable linguistic usage in the target language, and Gass and Selinker (2008) state that there are numerous ways of providing feedback to learners from the explicit (stating that there is a problem) to the implicit
Table 1. Distribution of participants according to their language levels.

\begin{tabular}{lcc}
\hline Participants & No & $\%$ \\
\hline C1 Level & 141 & 85.5 \\
B2 Level & 24 & 14.5 \\
TOTAL & 165 & 100 \\
\hline
\end{tabular}

(feedback during the course of interaction).

The second research question in the questionnaire was 'When should learner errors be corrected?' In Table 4, the findings from this question are presented.

According to Table 4, the majority of both $\mathrm{C} 1$ and $\mathrm{B} 2$ level participants (58.9\% overall) prefer to be corrected 'immediately', $36.2 \%$ of them prefer to be corrected when they finish their utterance, and a small minority of them $(4.9 \%)$ prefer to be corrected at the end of the lesson. A higher proportion of participants in level B2 (79.2\%) indicated a preference for immediate correction, while it lowered for those in $\mathrm{C} 1$ level $(55.4 \%)$. In other words, the B2 participants showed a stronger preference to be corrected immediately than the $\mathrm{C} 1$ participants. One possible explanation for this result may be the selfconfidence of the learner and their proficiency in the target language; when the proficiency increases, selfconfidence of the learner may increase as a consequence. This explanation requires further detailed qualitative research to be validated.

The third research question was about which types of errors learners preferred to be corrected. In Table 5, the responses of participants concerning which errors should be corrected are illustrated.

As can be seen in Table 5, the majority of both $\mathrm{C} 1$ and B2 level participants (54.0\% overall) agree that grammatical errors should be corrected primarily. Studying the breakdown figures, we see that $79.2 \%$ of B2 participants express a preference for correction of grammar errors, but a much lower $49.6 \%$ of C1 participants agree. While B2 participants wish secondarily for lexical error correction $(12.5 \%)$ and thirdly for pronunciation error correction $(8.3 \%)$, there is not a significant difference between the proportions of $\mathrm{C} 1$ level participants desiring these two types of correction: $24.5 \%$ for lexical and $25.9 \%$ for pronunciation errors. One possible explanation for these results is that lower level/proficiency learners (B2) need more structural support (grammatical and lexical) in the target language. As stated before, the participant of TFL learners are expected to continue their university education in Turkish in Turkey. Therefore, they need to become proficient enough in the language in order to follow academic and scientific Turkish. Loewen et al. (2009) state that 'ESL learners were less convinced about the need for grammar instruction and error correction and were more enthusiastic about improving communicative skills than were foreign language learners.' For example, learners of Arabic and Chinese 
Table 2. OCF choices of the questions.

\begin{tabular}{|c|c|c|c|c|}
\hline $\begin{array}{l}\text { Should errors } \\
\text { be corrected? }\end{array}$ & $\begin{array}{l}\text { When should errors } \\
\text { be corrected? }\end{array}$ & $\begin{array}{l}\text { Which errors should be } \\
\text { corrected? }\end{array}$ & $\begin{array}{l}\text { How should errors be } \\
\text { corrected? }\end{array}$ & $\begin{array}{l}\text { Who should } \\
\text { correct errors? }\end{array}$ \\
\hline Yes & Immediately & Grammar errors & $\begin{array}{l}\text { Teacher should give the } \\
\text { correct form immediately }\end{array}$ & $\begin{array}{lr}\text { Student } & \text { should } \\
\text { correct } & \text { by } \\
\text { him/herself } & \end{array}$ \\
\hline \multirow[t]{4}{*}{ No } & $\begin{array}{l}\text { At the end of the } \\
\text { utterance }\end{array}$ & Lexical errors & $\begin{array}{l}\text { Teacher should repeat the } \\
\text { incorrect part }\end{array}$ & $\begin{array}{l}\text { Teacher should } \\
\text { correct }\end{array}$ \\
\hline & $\begin{array}{l}\text { Altogether, at the end } \\
\text { of the lesson }\end{array}$ & Pronunciation errors & $\begin{array}{l}\text { Teacher should repeat the } \\
\text { sentence until the incorrect } \\
\text { part and then stop to allow } \\
\text { student to complete it } \\
\text { correctly }\end{array}$ & Other students \\
\hline & & & $\begin{array}{l}\text { Teacher should ask student } \\
\text { for the correct form }\end{array}$ & \\
\hline & & & $\begin{array}{l}\text { Teacher should indicate that } \\
\text { the student is incorrect by } \\
\text { means of body language }\end{array}$ & \\
\hline
\end{tabular}

Table 3. Participants' responses about whether errors should be corrected.

\begin{tabular}{lccc}
\hline & \multicolumn{3}{c}{ Should learners' errors be corrected? } \\
\hline & Yes (\%) & No (\%) & Total (\%) \\
\hline C1+B2 & 97.6 & 2.4 & 100 \\
C1 & 97.2 & 2.8 & 100 \\
B2 & 100.0 & 0.0 & 100 \\
\hline
\end{tabular}

Table 4. Participants' views regarding the timing of error correction.

\begin{tabular}{lcccc}
\hline \multicolumn{5}{c}{ When should learners' errors be corrected? } \\
\hline & Immediately (\%) & At the end of the utterance (\%) & Altogether, at the end of the lesson (\%) & Total (\%) \\
\hline C1+B2 & 58.9 & 36.2 & 4.9 & 100 \\
C1 & 55.4 & 39.6 & 5.0 & 100 \\
B2 & 79.2 & 16.7 & 4.1 & 100 \\
\hline
\end{tabular}

Table 5. Participants' views regarding which errors should be corrected

\begin{tabular}{lcccc}
\hline \multicolumn{5}{c}{ Which learners' errors should be corrected? } \\
\hline & $\begin{array}{c}\text { Grammar errors } \\
(\%)\end{array}$ & $\begin{array}{c}\text { Lexical errors } \\
(\%)\end{array}$ & $\begin{array}{c}\text { Pronunciation errors } \\
(\%)\end{array}$ & Total (\%) \\
\hline C1+B2 & 54.0 & 22.7 & 23.3 & 100 \\
C1 & 49.6 & 24.5 & 25.9 & 100 \\
B2 & 79.2 & 12.5 & 8.3 & 100 \\
\hline
\end{tabular}

were more positive about grammar and error correction then were learners of other languages. In another study, Katayama (2007) states that $77 \%$ of the students agreed teachers should correct their speaking errors to improve their accuracy.

Considering the literature, studies are conducted both 
Table 6. Participants' views regarding how errors should be corrected.

\begin{tabular}{lcccccc}
\hline & \multicolumn{5}{c}{ How should learners' errors be corrected? } \\
\hline $\begin{array}{c}\text { Teacher } \\
\text { should give } \\
\text { the correct } \\
\text { form } \\
\text { immediately } \\
(\%)\end{array}$ & $\begin{array}{c}\text { Teacher } \\
\text { should } \\
\text { repeat the } \\
\text { incorrect } \\
\text { part (\%) }\end{array}$ & $\begin{array}{c}\text { Teacher should repeat } \\
\text { the sentence until the } \\
\text { incorrect part and then } \\
\text { stop to allow the } \\
\text { student to complete it } \\
\text { correctly (\%) }\end{array}$ & $\begin{array}{c}\text { Teacher should } \\
\text { ask student for } \\
\text { the correct form } \\
(\%)\end{array}$ & $\begin{array}{c}\text { Teacher should } \\
\text { indicate that the } \\
\text { student is } \\
\text { incorrect by } \\
\text { means of body } \\
\text { language (\%) }\end{array}$ & Total (\%) \\
\hline C1+B2 & 43.0 & 21.2 & 17.0 & 10.7 & 8.1 & 100 \\
C1 & 44.2 & 23.2 & 17.4 & 8.0 & 7.2 & 100 \\
B2 & 41.7 & 12.5 & 16.7 & 20.8 & 8.3 & 100 \\
\hline
\end{tabular}

from the point of view of teachers and students, and the results vary upon the perspective. In his review of a number of studies, Chaudron (1988) states that teachers focus more on discourse, content and lexical errors than phonological and grammatical errors. However, in the present study, participants prefer primarily for their grammatical errors to be corrected. Another example, Brown (2009), is a study about ideal effective teacher behavior in foreign language teaching, and it is stated in that study that while students seem to favor a grammarbased approach, teachers prefer a more communicative classroom. It is clear that more detailed descriptive research is needed, examining both teacher and student perspectives, and the most common errors in accordance with the language and language levels.

The forth research question in the questionnaire was 'How should learner errors be corrected?'. In Table 6, responses of participants are presented regarding how learners' errors should be corrected.

As can be seen in Table 6 , the majority of both $\mathrm{C} 1$ and B2 level participants (43.0\% overall) prefer the method of error correction where the teacher gives the correct form immediately, and secondly they prefer the teacher to repeat the erroneous part of speech $(21.2 \%)$; the least desired $(8.1 \%)$ correction type is teachers' use of gestures, mimics, body language, etc. to indicate that student's utterance is erroneous. The ranking of strategies by $\mathrm{C} 1$ participants matches the overall order, but B2 participants' rankings are different. The majority of B2 participants $(41.7 \%)$ prefer the teacher to give the correct form immediately but their secondary choice $(20.8 \%)$ is waiting for the teacher to ask about the rule. This third most preferred strategy is for the teacher to repeat the sentence until the erroneous point and then stop to let student give the correct form (16.7\%). The least preferred correction type (8.3\%) is in accordance with the overall result, namely teachers' use of gestures, mimics, body language, etc.

In the second question, participants were asked when they should be corrected and the majority of them indicated a preference to be corrected 'immediately'; this result is compatible with the results of fourth question, which revealed that students prefer to be corrected by the teacher immediately. Bölükbaş (2011) states that the teacher should correct errors indirectly. Thus the student finds out the mistake by her/himself and gains courage in the target language. Present findings suggest that lower proficiency learners are more focused on the structure of the language and they are less interested in non-verbal corrections such as gesture, mimic or body language in the language learning process.

The study conducted by Fidan and İnan (2012) about OCF patterns in B2 level TFL classes states that one of the most common CF types that teachers use in the classroom is recast, and the least commonly used type is repetition. These findings are consistent with the studies conducted by Lyster and Ranta (1997) and Lyster (1988). However, the finding of the present study related to repetition is not consistent with the above studies. While repetition is the second the most preferred corrective strategy across all the participants, the above studies indicate that it is the least used one in the classroom by teachers. This finding suggests that learners' expectations and teachers' preferences may differ. This is why detailed future studies are needed in the field.

The fifth research question in the questionnaire was 'Who should correct the learners' errors?' In Table 7, the findings regarding the preferred person to correct errors are presented.

As can be seen from Table 7, the majority of both $\mathrm{C} 1$ and B2 level participants (73.2\% overall) prefer teachers to correct their errors. This finding is similar that of the study by Katayama (2007), which states that students had strongly positive attitudes toward teacher correction of errors. On the other hand, when the C1 and B2 participants in the present study are compared to each other, even though the majority of B2 participants $(66.7 \%)$ prefer teachers, the preference rate is somewhat higher in $\mathrm{C} 1$ participants (74.9\%). While $33.3 \%$ of B2 level participants prefer to correct their errors by themselves, the rate goes down to $23.7 \%$ for $\mathrm{C} 1$ participants. Peer-correction develops learners' interlanguage grammar (Crookes and Chaudron, 2001) but in the present study peer-correction is the lowest preference among the participants. This finding is interesting and it may be linked to the individual differences such as 
Table 7. Participants' views regarding who should correct errors.

\begin{tabular}{lcccc}
\hline \multicolumn{5}{c}{ Who should correct the learners' errors? } \\
\hline & Student by him/herself (\%) & Teacher (\%) & Other students (\%) & TOTAL (\%) \\
\hline C1+B2 & 25.2 & 73.2 & 1.6 & 100 \\
C1 & 23.7 & 74.9 & 1.4 & 100 \\
B2 & 33.3 & 66.7 & 0.0 & 100 \\
\hline
\end{tabular}

shyness, lack of self-confidence, fear of making mistakes, or cultural backgrounds of learners. Katayama (2007)'s study is a good example of the effects of cultural background. In the study, a total of $50.6 \%$ of participants agreed that they want their classmates to correct their oral errors in group work. She states that Japanese students have negative attitudes toward peer-correction because peer-correction violates the concept of in-group harmony. However, conducting further qualitative research will contribute to the field.

In the study of Bang (1999; in Loewen, 1999), most of the students agreed that oral correction is necessary, but they disagreed about when and how should it be executed. The study's findings are consistent with those of the present study. There are differences in the distribution of TFL learners' preferences between the groups ( $\mathrm{C} 1$ and $\mathrm{B} 2$ ) about when, how and by whom should it be done. However, there are common preferences as well; the majority of all TFL learners prefer teachers to correct them immediately, they prefer grammatical errors to be corrected primarily, and the most preferred correction strategy is teachers giving the correct form immediately.

\section{RECOMMENDATIONS FOR FURTHER RESEARCH}

It is commonly accepted that students' errors should be corrected so as to make them aware of the proper target language usage. However, there are no fixed strategies that can be applied universally on any occasion, as is seen in the above discussions. Studies that are related to oral classroom discourse activities - such as Kayı (2010), Fidan and İnan (2012), İnan and Fidan (2013) - on Turkish as a foreign/second language are seemingly very few. In the present study, TFL learners' remarks related to OCF are investigated. Nonetheless, the present study did not ask learners to justify their responses. Future studies should therefore be carried out, with more participants from every level of learning (from A1 to C1), and asking for justifications will lead to improvement of understanding in error treatment in Turkish as foreign/ second language classrooms.

Kayı (2010), in a qualitative study, investigates recast in a TFL class and she states that opinions of students differ related to recast. It is seen as a developer of intrinsic motivation or seen as an inhibitor of the motivation. Thus, taking into consideration individual differences, this is another important issue for TFL studies requiring more detailed work.

Schulz (2001) mentions the significance of teacher education programs and how important they are in changing teachers' perceptions of effective error correction. In order to schedule an efficient teacher education program like the one Schulz proposes, the most common error lists for every level (A1, A2, B1, B2, C1), both for oral and for written language, should be prepared for Turkish. While preparing these kinds of lists, both learners and teachers should be asked about their experiences when they were learning/teaching Turkish. This is why further studies examining the needs of learners and teachers will be helpful especially when preparing materials such as teacher books, course books, etc.

\section{Conflict of Interests}

The author has not declared any conflict of interests.

\section{ACKNOWLEDGEMENT}

The author is thankful to the students for their cooperation in data collection. Thanks are dueto Fatma Bölükbaş and Funda Keskin who helped to reach some of the participants. In addition to this, special thanks are due to Tuğba Erdoğan and Levent Fidan for their assistance with data entry, and to Assist. Prof. Dr. Fatih Kezer for his help to analyse the data. Special thanks are due to Daniel Austin for proofreading this paper as a native speaker of English. Finally, deepest regards are to my family who have always been supportive and who were ever patient with me during writing.

\section{REFERENCES}

Bölükbaş F (2011). Arap Öğrencilerin Türkçe yazılı anlatım becerilerinin değerlendirilmesi. Turkish Studies-International Periodical For The Languages, Literature and History of Turk. Turkic. 6(3):1357-1367.

Brown AV (2009). Students' and teachers' perceptions of effective foreign language teaching: A comparison of ideals. Modern Language J. 93(1):46-60.

Chaudron C (1977). A Descriptive Model of Discourse in the Corrective Treatment of Learners' Errors. Language Learn. 27:29-46.

Chaudron C (1988). Second Language Classrooms: Research on Teaching and Learning. Cambridge: Cambridge University Press.

Council of Europe (2001). Common European Framework of References for Languages: Learning, teaching, assessment. Cambridge: Cambridge University Press. 
Crookes G, Chaudron C (1991). Guidelines for language classroom instruction. In: M. Celce-Murcia (ed). Teaching English as a Second or Foreign Language ( $3^{\text {rd }}$ Edition). Boston: Heinle \& Heinle. pp.29-42. Retrieved Oct.7.2014 from http://sls.hawaii.edu/Gblog/wpcontent/uploads/2011/08/Crookes-Chaudron-2001-guidelines.pdf

Ellis $R$ (2008). The Study of Language Acquisition. ( $2^{\text {nd }}$ ed.) Oxford: Oxford University Press.

Gass SM, Selinker L (2008). Second Language Acquisition: An Introductory Course ( $3^{\text {rd }}$ edition) New York: Routledge.

Fidan D, Inan B (2012). Oral corrective feedback patterns in Turkish as a foreign language (TFL) classes. In: M. Aksan, A. Ucar (ed.) Proceedings of the $5^{\text {th }}$ Internationa Turkish Language Teaching Conference, Ankara: TUBITAK, pp.119-127.

Hendrickson $\mathrm{J}$ (1978). Error correction in foreign language teaching: Recent research and practice. Modern Language J. 62:387-398.

Katayama A (2007). Learners' perception toward oral error correction. In: K. Bradford-Watts (Ed.). JALT2006 Conference Proceedings. Tokyo: JALT, pp.284-299.

Inan B, Fidan D (2013). Teacher questions and their functions in Turkish as a foreign language (TFL) classes. Precedia Social Behav. Sci. 70:1070-1077.

Kayı $\mathrm{H}$ (2010). Recast in a Turkish as a foreign language classroom: A way to intrinsic motivation? TPFL 14 (1):28-40.
Loewen S, Li S, Fei F, Thompson A, Nakatsukasa L, Ahn S, Chen X (2009). Second language learners' beliefs about grammar instruction and error correction. Modern Language J. 93 (1):91-104.

Lyster R (1998). Negotiation of form, recast and explicit correction in relation to error types and learner repair in immersion classrooms. Language Learn. 48(2):183-218.

Lyster R, Ranta L (1997). Corrective feedback and learner uptake: negotiation of form in communicative classrooms. Studies in Second Language Acquisition 19:37-66.

Schulz RA (2001). Cultural differences in student and teacher perceptions concerning the role of grammar instruction and corrective feedback. The Modern Language J. 85 (2):244-258.

Sheen $Y$ (2011). Corrective feedback, individual differences and second language learning. New York: Springer.

Walsh S (2013). Classroom Discourse and Teacher Development. Edinburgh: Edinburgh University Press. 